\title{
An Investigative Analysis on Prediction of Crude Oil Price in the Philippines using Artificial Neural Network
}

\author{
J. Domondon Urrutia ${ }^{1}$, J. L. Meneses ${ }^{2,3}$ and P. I. M. Estolano ${ }^{4 *}$ \\ 'Research Management Office, Polytechnic University of the Philippines, Manila, \\ Philippines; jdurrutia@pup.edu.ph, jackieurrutia20@gmail.com \\ ${ }^{2}$ Research and Extension Services, Rizal Technological University, Manila, Philippines \\ ${ }^{3}$ Asia University, Taichung, Taiwan; jlmeneses@rtu.edu.ph \\ ${ }^{4}$ Land Bank of the Philippines, Batangas, Philippines; precious.estolano@gmail.com
}

\begin{abstract}
Objective: The Crude Oil industry plays a substantial role in the Philippine economy. The researchers intended to compare models of NARX Neural Network and Multiple Linear Regression through the forecast of the Crude Oil price in the Philippines (y) and prediction of the values from October 2018 to December 2023. Methods/Statistical Analysis: The researchers observed the behaviour of the factors that impact the Crude Oil price in the Philippines $(y)$ and with the application of Multiple Linear Regression (MLR), concluded that among the factors, the substantial predictors are Inflation Rate $\left(\mathrm{x}_{2}\right)$, Consumption of Crude Oil $\left(\mathrm{x}_{5}\right)$, Import of Crude Oil $\left(\mathrm{x}_{7}\right)$ and Export of Crude Oil $\left(\mathrm{x}_{8}\right)$ while - Exchange rate $\left(\mathrm{x}_{1}\right)$, Consumer price index $\left(\mathrm{x}_{3}\right)$, Domestic interest rate $\left(\mathrm{x}_{4}\right)$ and Production of Crude Oil $\left(\mathrm{x}_{6}\right)$ are not. Also, NARX Neural Network was used to predict the Crude Oil prices in the Philippines from October 2018 to December 2023. Findings: Through using the NARX Neural Network, researchers were able to come up with the predicted Crude Oil prices in the Philippines and concluded that their behaviour fluctuates. Improvement: Novelty of work is NARX Neural Network which is the best-fitted model in predicting the Crude Oil price in the Philippines. Thus, predicted values are highly precise.
\end{abstract}

Keywords: Artificial Neural Network, Crude Oil Price in the Philippines, Forecasting Accuracy, Multiple Linear -Regression, NARX Neural Network

\section{Introduction}

Crude Oil is among the world's most vitalenergy resources, excluding fuel for energy and transport; it is conjointly used for varied functions even in households or industries. Crude Oil prices have affected the Philippine economy adversely in decades since then 1 . During the year 1993, the Philippines experienced severe scarcity inflicting the declination of the economy. This created a colossal result within the crude industry of the Philippines. Despite this, in 1993, the Philippine National Oil Company (PNOC), which was established on November 09, 1973 through
Presidential Decree No. 334, entered into the venture of petrochemicals. Its intention is to run and preserve steady supply of oil within the country ${ }^{2}$. PNOC set up the country's first petrochemical industrialized manor in Limay, Bataan.

One of the subsidiaries of PNOC is the PNOC Exploration Corporation (PNOC EC). It was incorporated on April 20, 1976 that is mandated by the government to entail the lead within the probe, development, and fabrication of the country's oil, gas and coal resources through the support of the Department of Energy (DOE) ${ }^{3}$. 
The PNOC EC was converted to the $3 \mathrm{MW}$ San Antonio Gas Power Plants in 1994. The San Antonio Gas Power Plant was located in the municipality of Echague, Isabela. It started its production in 1994 and was able to produce $3.54 \mathrm{BCF}$ of gas until it was decommissioned in $2008^{7}$.

The government then created the Downstream Oil Industry Deregulation Act of 1998 which states that the government is not permitted to interfere with the pricing, importation, and exportation of oil products.

Even the institution of gas stations, storage, depots, ocean-receiving facilities and gas refineries is prohibited. This Act triggered extreme competition within the market that resulted to unstable pricing of Crude Oil products ${ }^{5}$.

In 2001, the Malampaya Gas Field commenced its operation. The field, since then, has been a stable source of supply of energy that meets thirty five to forty percent of Luzon's power necessities ${ }^{6}$. This project that uses progressive deep-water technology to draw natural gases from deep beneath Philippine waters is the first of its kind within the Philippines. The indigenous gas fuels three natural gas-fired power stations with a total generating capacity of 2,700 megawatts. This is considered the most common and thriving project of the PNOC EC, having the ability to affix with the rank of other petroleum majors such as Shell Exploration and Texaco.

At present, there are already seven (7) petroleum Service Contracts in the Philippines that are owned by PNOC EC. The SC 37 is located in Cagayan Basin. The others are located in Northwest Palawan, SC 75, in Calamian, SC 57, in West Calamian, SC 58, in West Balabac, SC 59, in Northwest Palawan, SC 74 and SC 63 which is located in East Sabina. SC 3 and SC 63 are being operated by PNOC EC while it plays as a non-operating partner in SC 38, SC 57, SC 58 and SC 59․․․

Another government controlled subsidiary of PNOC is the PNOC Renewables Corporation (PNOC RC). It was organized and incorporated on March 7, 2008 that has an objective to become the prime vehicle of the government in stimulating, emerging and instigating renewable energy and energy potency agendas within the country. Renewable Energy plays a substantial part in the shift towards a low carbon economy. Hence, one of the company's intents is to advocate low carbon development methods that would remarkably sustain the Energy sector's goals of warranting adequate, steady, secure, accessible and reasonably-priced energy supply and tailing cleaner and adept energy utilization and clean technologies implementation ${ }^{?}$.

\section{Objective of the Study}

This research intends to predict the monthly Crude Oil Price in the Philippines (y) from October 2018 to December 2023. This also aims to discern the graphs of the independent variables: Exchange Rate $\left(\mathrm{x}_{1}\right)$, Inflation Rate $\left(\mathrm{x}_{2}\right)$, Consumer Price Index $\left(\mathrm{x}_{3}\right)$, Interest Rate $\left(\mathrm{x}_{4}\right)$, Crude Oil Consumption $\left(\mathrm{x}_{5}\right)$, Crude Oil Production $\left(\mathrm{x}_{6}\right)$, Crude Oil Import $\left(\mathrm{x}_{7}\right)$ and Crude Oil Export $\left(\mathrm{x}_{8}\right)$. Also, to distinguish which between Multiple Linear Regression (MLR) and Nonlinear Autoregressive Exogenous Neural Network is the best-fitted model in predicting the Crude Oil Price in the Philippines (y).

\section{Conceptual Framework}

\subsection{Statement of the Problem}

The aim of this research is to answer the following questions:

- What is the behaviour of the graph of the Crude Oil Price in the Philippines ( $y$ ) and behaviour of the graphs of the independent variables?

$$
\begin{aligned}
& >\text { Exchange Rate }\left(\mathrm{x}_{1}\right) . \\
& >\quad \text { Inflation Rate }\left(\mathrm{x}_{2}\right) . \\
& >\quad \text { Consumer Price Index }\left(\mathrm{x}_{3}\right) . \\
& >\quad \text { Interest Rate }\left(\mathrm{x}_{4}\right) . \\
& >\quad \text { Crude Oil Consumption }\left(\mathrm{x}_{5}\right) . \\
& >\quad \text { Crude Oil Production }\left(\mathrm{x}_{6}\right) . \\
& >\quad \text { Crude Oil Import }\left(\mathrm{x}_{7}\right) .
\end{aligned}
$$

- Is there a significant relationship among the Exchange Rate $\left(\mathrm{x}_{1}\right)$, Inflation Rate $\left(\mathrm{x}_{2}\right)$, Consumer Price Index $\left(\mathrm{x}_{3}\right)$, Interest Rate $\left(\mathrm{x}_{4}\right)$, Crude Oil Consumption $\left(\mathrm{x}_{5}\right)$, Crude Oil Production $\left(\mathrm{x}_{6}\right)$, Crude Oil Import $\left(\mathrm{x}_{7}\right)$, Crude Oil Export $\left(\mathrm{x}_{8}\right)$ and the Crude Oil Price in the Philippines (y)?

- What are the important predictors of Crude Oil Price in the Philippines (y)? 
- What is the best-fitted model in predicting the Crude Oil price in the Philippines (y)?

- What is the predicted monthly Crude Oil Price in the Philippines (y) from October 2018 to December 2023?

\section{Scope and Limitation}

This study encompasses the monthly data of the Exchange Rate $\left(\mathrm{x}_{1}\right)$, Inflation Rate $\left(\mathrm{x}_{2}\right)$, Consumer Price Index $\left(\mathrm{x}_{3}\right)$, Interest Rate $\left(\mathrm{x}_{4}\right)$, Crude Oil Consumption $\left(\mathrm{x}_{5}\right)$, Crude Oil Production $\left(\mathrm{x}_{6}\right)$, Crude Oil Import $\left(\mathrm{x}_{7}\right)$, Crude Oil Export $\left(\mathrm{x}_{8}\right)$ and the Crude Oil Price in the Philippines(y) from January 1993 to October 2018. Furthermore, this research predicts the values of Crude Oil price in the Philippines (y) from October 2018 to December 2023.

\section{Significance of the Study}

One of the most substantial products in the international market is the crude oil. It plays a dominant role in the country's sustainability and economic stability. Crude Oil price is measured as an inclusive economic indicator that is why price fluctuations are observed systematically by the government, oil companies, speculators, hedgers, investors, dealers, and consumers. This study would serve as a guide to future consumers in distinguishing the Crude Oil prices and for them to ascertain what appropriate methods to take in handling the variations.

\subsection{Review of Related Literature}

In $^{8,9}$ used multiple linear regression to analyse arrays of exchange rate volatility and the estimated regression coefficients. He explored these variables and was able to display the impact of currencies of some of the advanced countries as nominal anchors for the exchange rates from the chosen markets and then broken down in three shorter sets of data.

In ${ }^{10}$ acknowledged the variables that affect the oilfield's output's performance using multiple linear regression. The authors concluded that the percentage error of predicted value from the actual output is only $4.57 \%$ which shows that we can apply this method to forecast the oilfield output.

In ${ }^{11}$ made an effort for the more precise prediction of the foreign exchange rate. He used the data of a shorter timeframe for the observation of Indian rupee and USA dollar exchange rate having the World Bank indicator and few economic indicators. NARX was trained with exogenous variables of past years and NARX was determined as a very effective neural network in predicting the foreign exchange rate.

$\mathrm{In}^{12}$ analysed the inflation rate in Sudan using econometric time series models. This study concluded that the models fulfilled all the economic theories, statistical and econometric criteria. Moreover, it fulfilled the conditions of the best regression model. The inflation rate model has 0.98 coefficient determination and this indicates superiority of the model.

$\mathrm{In}^{\frac{13}{3}}$ using stepwise multiple regression, forecasted Malaysia's crude material imports. In this study, MLR recognized four models and the study proved that among the four models, model 1 or the Linear Model is the best. Furthermore, the findings revealed that only four controlled variables influence the value of imports. These variables predict price index of (CM), Gross Domestic Products (GDP) and the value of exports and the average sales tax of (CM).

Select a dynamic ANN as a nonlinear artificial model. This was chosen since traditional and statistical econometric models are inapt in forecasting Crude Oil prices. He examined the aptitude of the NARX method to make an accurate forecast. Furthermore, he concluded that ANN makes a great predictive ability for Crude Oil price forecasting.

In ${ }^{14}$ scrutinized the efficiency of the NARX framework in volatility forecasting in the Nigerian Crude Oil market through a study conducted in 2016. They recommended two hybrid models such as NARX I and II. NARX I is used as inputs volatility estimates attained by the fitted GARCH model as well as other endogenous variables. On the other hand, NARX II takes simulated volatility series as extra inputs. As the initial step, a GARCH type model was acknowledged upon which the hybrid model is built. The outputs of the traditional GARCH models show that the EGARCH $(3,3)$ best fits the noise of the Crude Oil price. Hence, this was used for the construction of the hybrid models. It was proven that NARX II provides better volatility outperforming the two other models.

Also in $\frac{15}{15}$ intended to predict movements in Forex market based on the NARX Neural Network using timeshifting bagging technique and financial indicators. These financial indicators include relative strength index and stochastic indicators. The study presented the advantage of considering NARX Neural Network and time shifting 
bagging technique with some external indicators when predicting the Forex market movement.

$\operatorname{In}^{16}$ used in their study four different approaches namely; GARCH $(1,1$,$) , GARCH (2,2)$, EGARCH $(1,1)$ and EGARCH $(2,2)$. This study shows a comparative analysis of the ANN-based models and the econometric models. Moreover, it revealed that MLFFNN and NARX are better methods in terms of predictive efficiency.

A study published by ${ }^{17}$ in 2017 presented that the weather, natural factor and national policy decisions will interminably diminish the crude oil's future price at a certain time, which will make the analysis model have a transient failure. The authors established that the analysis method and the analytical model of this study do not have the effect of short-term prediction.

$\operatorname{In}^{\underline{18}}$ used multiple linear regressions with two different approaches, considering original data and principal component as inputs, to forecast the next month Consumer Price Index. The findings revealed that the use of the principal component as input gives a more precise result than original data because it focused the number of inputs and therefore decreased the model complexity. Furthermore, the use of principal component-based models was considered more effective, due to eradication of collinearity problem and reduction of the number of predictor variables.

$\operatorname{In}^{19}$ concluded that the neural network-based modelling gives better accuracy than regression. Their study also showed that ARIMA models and neural network was a clear winner in terms of generalization and the ability to follow changing trends in the out-ofsample forecast. It also demonstrates real potential in multivariate forecasting of Crude Oil prices.

$\mathrm{In}^{20}$ deliberated new methodologies of NARX-based Forecasting Model. Their case study indicated that NARX neural networks have good potential in learning and understanding stock market developments.

In ${ }^{21}$ studied about regression analysis of determinants influencing Crude Oil price, labelled a new model of the most substantial factors that affect Crude Oil prices by using a new method referred as principal component analysis (PCA) ${ }^{22}$. This study determined that the most significant factors that affect Crude Oil prices are the fundamentals and the role of the organization of petroleum exporting countries.

\section{Methodology}

\subsection{Statistical Methods}

\subsubsection{Pearson's Correlation Coefficient}

Pearson R is a correlation statistic most generally used to measure the degree of association between continuous linearly connected variables ${ }^{23}, 24$. To envision for linearity between two continuous variables, the preliminary stage is to draw a scatter plot of the variables. The coefficient of correlation should not be computed for if the relationship between variables is not linear. It does not matter on which axis the variables are plotted in correlation functions. However, conservatively, the independent variables, also called the explanatory variables, are plotted on the $\mathrm{x}$-axis (horizontally). On the other hand, on the $y$-axis (vertically) lie the dependent variables or response variables.

The Pearson $r$ is given by:

$$
r=\frac{N \sum x y-\left(\sum x\right)\left(\sum y\right)}{\sqrt{\left[N \sum x^{2}-\left(\sum x\right)^{2}\right]\left[N \sum y^{2}-\left(\sum y\right)^{2}\right]}}
$$

Where

$N=$ number of pair scores.

$\sum x y=$ Sum of the products of paired scores.

$\sum x=$ Sum of the $x$ scores.

$\Sigma y=$ Sum of the $y$ scores.

$\sum x^{2}=$ Sum of the squared $x$ scores.

$\Sigma y^{2}=$ Sum of the squared $y$ scores.

The closer the scatter of points is to a straight line, the greater the strength of the association there is between the given variables. Conjointly, it does not matter what measurement units are used ${ }^{25}$.

\subsubsection{Multiple Linear Regressions}

Multiple Regressions is used to compute whether there is a linear relationship between the dependent variables and an independent variable. Equation for multiple linear regressions is exhibited as:

$$
\hat{Y}=b_{0}+b_{1} X_{1}+b_{2} X_{2}+\ldots+b_{p} X_{p}
$$


Where $\hat{Y}$ is the expected or predicted value of the dependent variable, $\mathrm{X}_{1}$ through $\mathrm{X}_{\mathrm{p}}$ are $p$ distinct predictor or independent variables, $b_{0}$ is the value of $\mathrm{Y}$ when all of the independent variables $\left(\mathrm{X}_{1}\right.$ through $\mathrm{X}_{\mathrm{p}}$ ) are equal to zero and $b_{1}$ through $b_{p}$ is the estimated regression coefficients. Each regression coefficient signifies the change in $\mathrm{Y}$ relative to a one-unit variation in the respective independent variable. Statistical tests can be done to quantify whether each regression coefficient is significantly different from zero ${ }^{26}$.

Assumptions:

- The relationship between the dependent variables and the independent variables is linear.

- There is no multi-collinearity in the data.

- The values of the residuals are independent.

- The variance of the residuals is constant.

- The values of the residuals are normally distributed.

\subsubsection{Non-linear Auto-regressive Network with Exogenous Inputs}

The nonlinear auto-regressive exogenous neural network prototype is founded on the linear ARX model that is frequently used in time series modelling. The NARX equation is computed as:

$$
\begin{aligned}
& y(t)=f\left(y(t-1), y(t-2), \ldots, y\left(t-n_{y}\right), u(t-1), u(t-2), \ldots,\right. \\
& \left.u\left(t-n_{u}\right)\right)
\end{aligned}
$$

Where the succeeding value of the dependent output signal $y(t)$ is regressed on preceding values of the output signal and an independent (exogenous) input signal.

Diagram 1 is illustrated as a resulting network diagram. It depicts where a two-layer feed forward network is used for the approximation. Not only can it be used as a predictor of the succeeding value of the input signal, it can also be used for nonlinear filtering, in which the target output is a noise-free form of the input signal. One can consider the output of the NARX to be an approximate of the output of some nonlinear dynamic system that one is trying to denote.

Diagram 2 illustrates the procedure of the seriesparallel architecture for training a NARX network to model a dynamic system. As shown in the left figure, the output is fed back to the input of the feed-forward neural network. On the other hand, as depicted in the right figure, the true output is used as a substitute of feeding back the estimated output. This provides two advantages; first, the resulting network has pure feed-forward architecture and static back-propagation can be used for training; the second is that the input to the feed-forward network is more accurate.

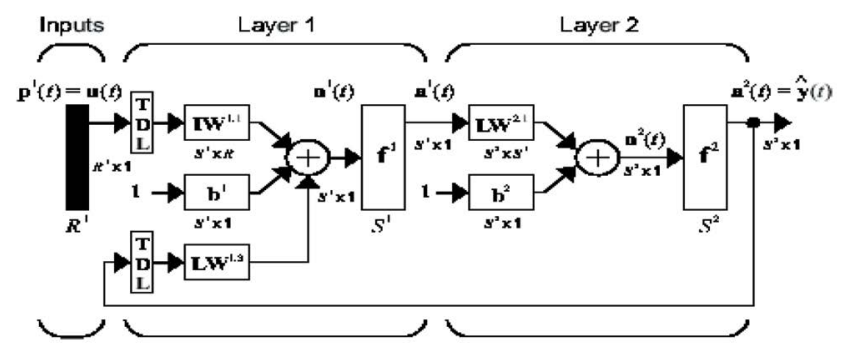

Diagram 1. NARX diagram.
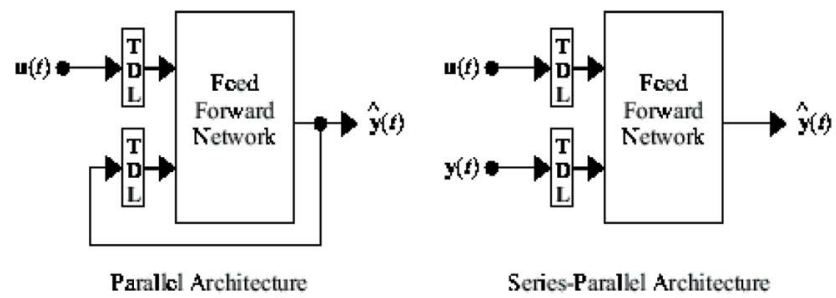

Diagram 2. NARX Architecture.

\subsubsection{Forecasting Accuracy}

\subsubsection{Mean Absolute Error (MAE)}

Mean Absolute Error (MAE) is the measurement of average vertical and the average horizontal distance between each point and the identity line. MAE is also used to calculate the average magnitude of the errors in a set of forecasts, without considering their directions. In addition to that, it is the average over the verification sample of the absolute values of the differences between predicted and the actual observation.

$M A E=\frac{1}{n} \sum_{i=1}^{n}\left|Y_{i}-\hat{Y}_{i}\right|$

Where:

$\mathbf{n}$ is the total number of data points.

$\mathrm{Y}$ is the actual output value.

$\hat{Y}$ is the predicted output value.

Figure 1 is a graphical depiction of the MAE. The green line represents the model's predictions, while the blue line points represent our data ${ }^{27}$. 


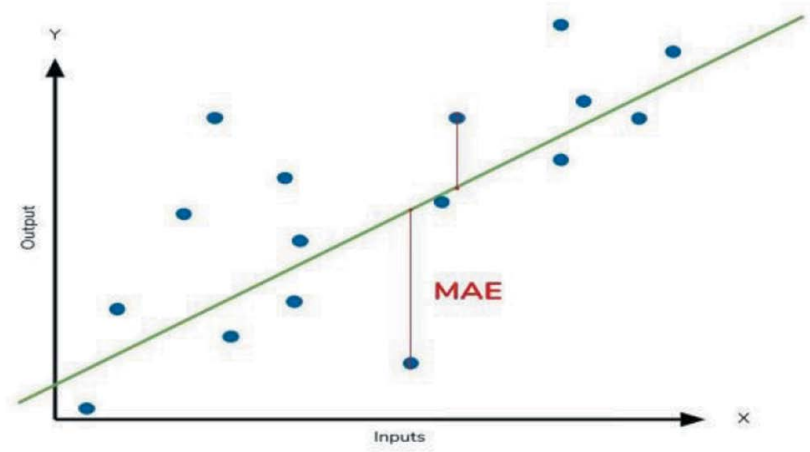

Figure 1. Mean Absolute Error [January 1993 - September 2018].

\subsubsection{Mean Absolute Percentage Error (MAPE)}

The Mean Absolute Percentage Error (MAPE) is the percentage equivalent of MAE; however, the use of MAPE is more limited. MAPE is also the most common measure of forecast error. It greatly functions when there are no extremes to the data (including zeros). Furthermore, MAPE is the average absolute percent error for each period or forecast minus actual divided by actual.

$$
\text { MAPE }=\frac{100 \%}{n} \sum_{i=1}^{n}\left|\frac{Y_{i}-\hat{Y}_{i}}{Y_{i}}\right|
$$

Similarly, the MAPE can propagate remarkably large if the actual values are notably small as shown in Figure 2. Finally, the MAPE is subjective towards forecasts that are systematically less than the actual values. Hence, MAPE will be lower when the prediction is lower than the actual in comparison to a prediction that is higher by the same amount ${ }^{28}$.

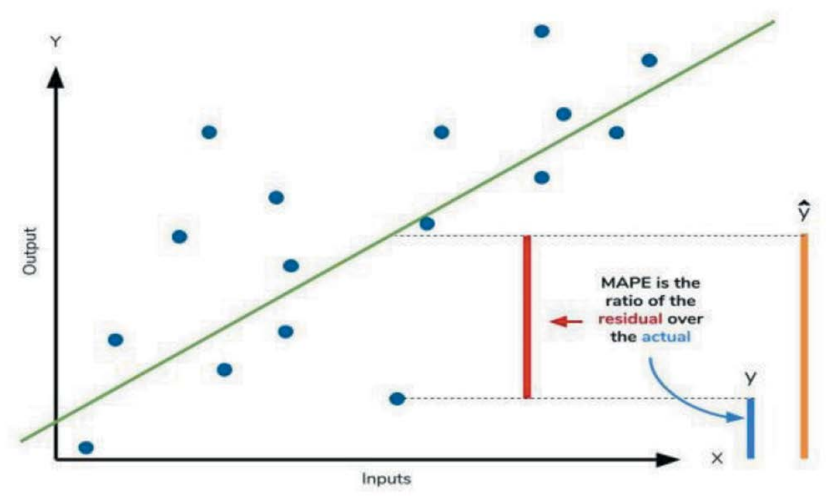

Figure 2. Mean Absolute Percentage Error.

\subsubsection{Mean Square Error (MSE)}

The Mean Square Error (MSE), as shown in Figure 3, is the average of the squared errors between actual and predicted values in a data sample. It is just like the MAE but uses squared difference instead of using absolute value since squaring the difference exterminates the probability of dealing with negative numbers ${ }^{27}$. Errors are calculated by getting the difference between the measured value and the predicted value at a particular time. MSE is given by:

$$
M S E=\frac{1}{n} \sum_{i=1}^{n}\left(Y_{i}-\hat{Y}_{i}\right)^{2}
$$

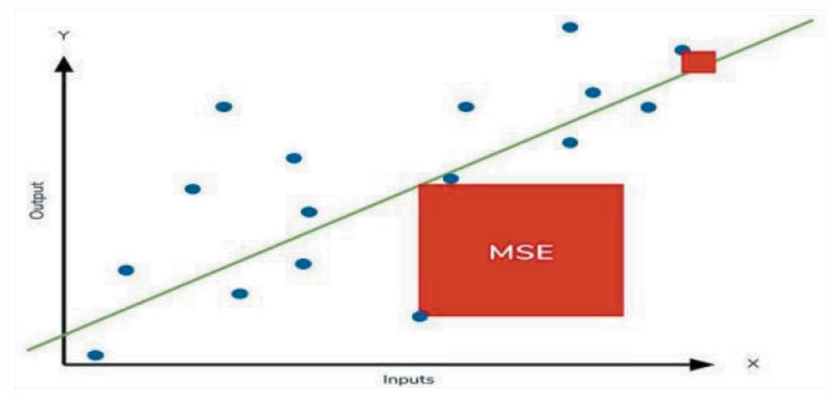

Figure 3. Mean Square Error.

\subsubsection{Root Mean Squared Error (RMSE)}

Root Mean Square Error (RMSE) is used to identify and calculate how much error there is between two sets of data, associating a predicted and an observed value. RMSE is also known as root mean square deviation and is also one of the most extensively used statistics in GIS 27 .

$$
R M S E=\sqrt{\frac{1}{n} \sum_{i=1}^{n}\left(Y_{i}-\hat{Y}_{i}\right)^{2}}
$$

\subsubsection{Normalized Mean Square Error (NMSE)}

Normalized Mean Square Error (NMSE) is an estimator of the overall or summed deviations between measured and predicted values ${ }^{29}$. It is well-performing both in space and time if a model has a very low NMSE. On the other hand, high NMSE values do not profoundly mean that a model is entirely incorrect. That case could be due to time and/or space-shifting ${ }^{30}$. It is computed as: 
NMSE $=\frac{1}{n} \sum_{i=1}^{n} \frac{\left(Y_{i}-\hat{Y}_{i}\right)^{2}}{\overline{Y_{i}} \overline{\hat{Y}}_{i}}$

Where

$\overline{Y_{i}}=\frac{1}{n} \sum_{i}^{n} Y_{i} a n d \overline{\hat{Y}}_{i}=\frac{1}{n} \sum_{i}^{n} \hat{Y}_{i}$

\section{Results and Discussion}

\subsection{Behavior of the Graph of the Dependent and Independent Variables}

\subsubsection{Crude Oil Price}

Crude Oil prices in the Philippines were lowest from 1993 to 1998 due to the government's policy identified as the Downstream Oil Industry Deregulation Act of 1998. The objective of this Act is to allow market competition without the government playing the role with the pricing, exportation, and importation of oil products ${ }^{5}$. In the following years, the graph displays a slight increase at first and then abruptly rising until it reached its peak in the year 2007. Moreover, in 2008 and 2014, Crude Oil prices decreased considerably when the government imposed the minimum inventory requirement in the downstream oil industry to guarantee perpetual, firm and soundly Crude Oil products in the Philippines ${ }^{31}$ (Figure 4).

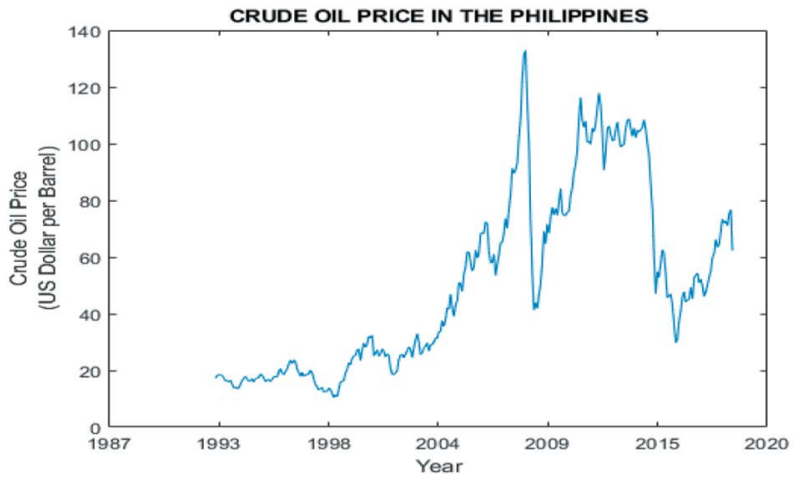

Figure 4. Crude Oil price in the Philippines (y).

\subsubsection{Exchange Rate}

Observing the illustration, it is perceptible that the exchange rates were at their lowest from 1993 until 1998 attributed to the incidence of Asian Contagion. The Asian financial crisis was a sequence of currency depreciations and other events. The currency first failed in Thailand as the consequence of the government's decision to no longer fix the local currency to the U.S. Dollar (USD). Currency declines spread suddenly throughout Southeast Asia including the Philippines. As shown in Figure 5, the consumer price inflation went up to $7.6 \%$ in 2005 from $3 \%$ in 2003 to $5.50 \%$ in 2004 . The rise in inflation replicated in the collective impact of a depreciating peso and rising petroleum prices causing the Philippines to grasp its peak in the exchange rate in 2004. After 2009, the exchange rate then declined again by $6.6 \%$ as the full impact of the global financial turmoil and the continued risk aversion against developing market economies. In 2015 to 2018, the exchange rate kept increasing as a result of low import in the Philippines ${ }^{32}$.

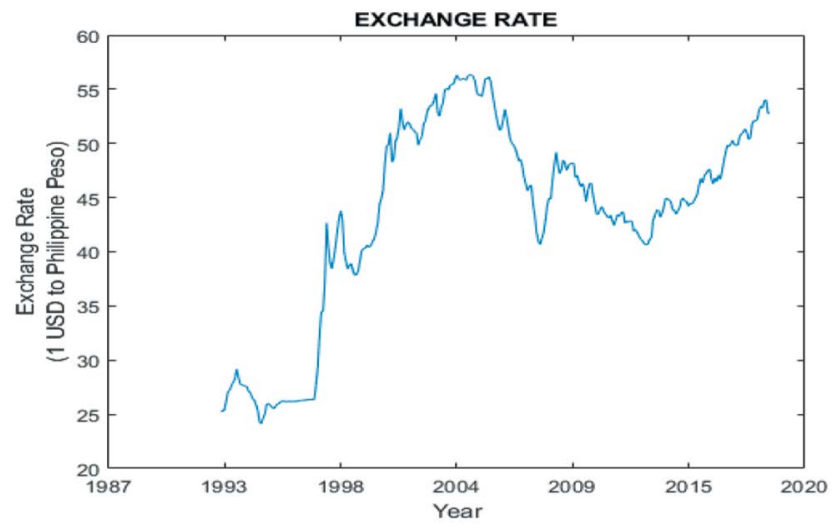

Figure 5. Exchange rate in the Philippines $\left(\mathrm{x}_{1}\right)$ [January 1993 - September 2018].

\subsubsection{Inflation Rate}

The Philippines' inflation rate declined in 2015 due to the slower surge in the price of the goods and services. According to the Bangko Sentralng Pilipinas (BSP) annual report the food inflation rate decreased by $2.6 \%$ in 2015 from $7.1 \%$ of the previous year. In 2008, as shown in Figure 6, the average of inflation reached 9.3\%. This increase can be attributed to the oil price hike and increased prices of basic commodities.

\subsubsection{Consumer Price Index}

Figure 7 depicts a steady increase of the consumer price index over the years. This can be attributed to the increasing population of the country that resulted to higher demands for the daily commodities. 


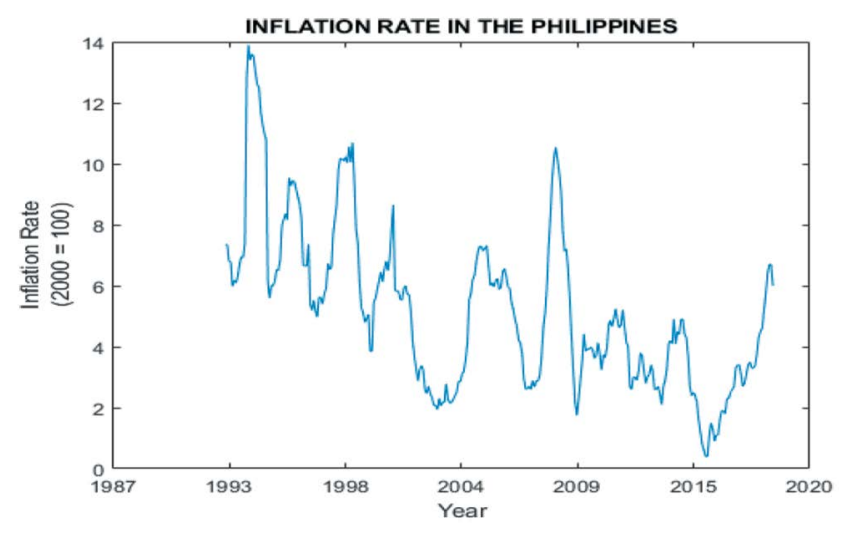

Figure 6. Inflation rate in the Philippines $\left(\mathrm{x}_{2}\right)$ [January 1993 - September 2018].

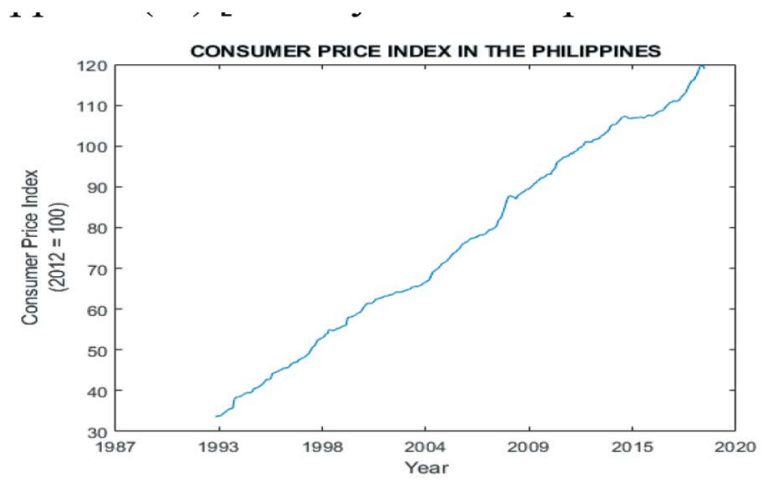

Figure 7. Consumer price index in the Philippines $\left(\mathrm{x}_{3}\right)$ [January 1993 - September 2018].

\subsubsection{Domestic Interest Rate}

Substantial variability of the domestic interest rate between 1993 and 2004 were illustrated in Figure 8. This may be attributed to the Asian Economic Crisis in 1997 to 1998 that triggered the Philippines' stock market to decline by $32 \%$. Moreover, the currency against the dollar had depreciated by as much as $48 \%$ and later level off at $30 \%$ at end of December 1997. A side from this, threats of terrorists and insurgency in the country at that time also resulted to slow economic growth and ambiguity ${ }^{33}$. Hence, the gradual decline of domestic interest rates in the preceding years.

\subsubsection{Consumption of Crude Oil}

Consumption of petroleum for the Philippines in December 2018 amounted to 487.47 thousand barrels per day. Though Philippine petroleum consumption fluctuated substantively in recent months, it inclined through January 2014 to December 2018 as shown in

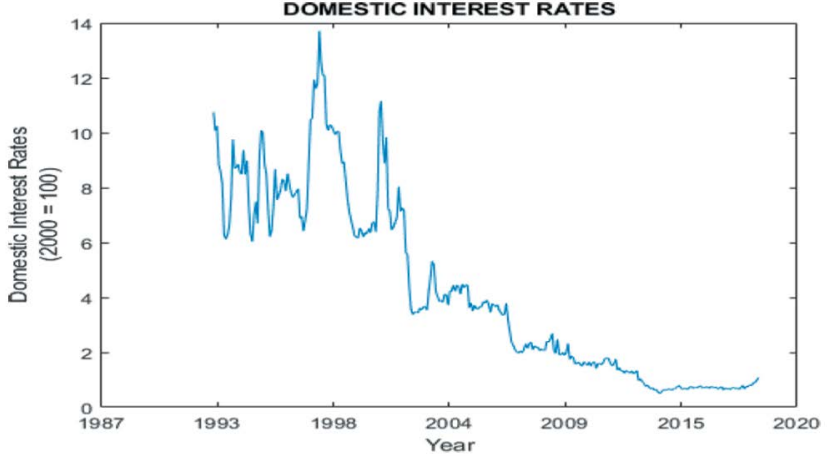

Figure 8. Domestic interest rates in the Philippines $\left(\mathrm{x}_{4}\right)$ [January 1993 - September 2018].

Figure 9, period ending at 487.47 thousand barrels per day in December $2018^{34}$.

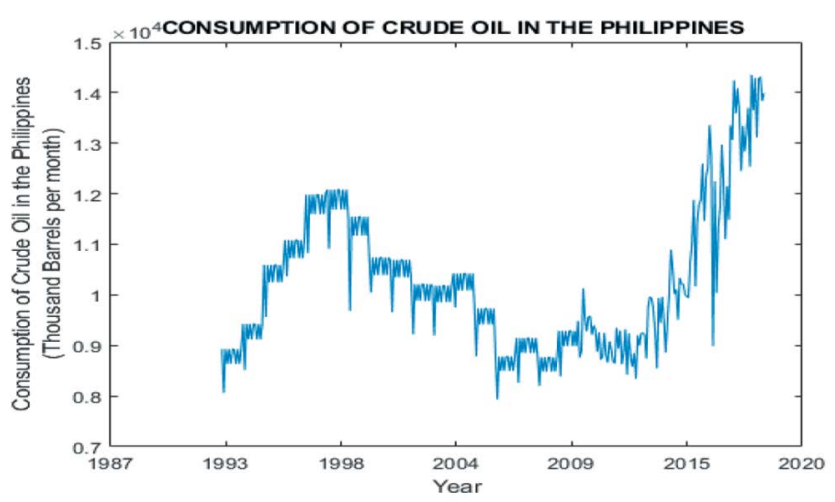

Figure 9. Consumption of Crude Oil in the Philippines $\left(\mathrm{x}_{5}\right)$ [January 1993 - September 2018].

\subsubsection{Production of Crude Oil}

Production of Crude Oil in the Philippines from 2005 until 2008 was stabilized as shown in Figure 10. It reached its peak production record in 2009 attributable to the pressure in the Gaza Strip. On the other hand, the increase in the importation of Crude Oil in the Middle East resulted to the lowest Crude Oil production that transpired between 2013 and 2018.

\subsubsection{Import of Crude Oil}

From the highest record of crude import around 1996, Figure 11 depicts a decline over the years up to its lowest record in 2008. This can be attributed to the initial production of Malampaya gas field. As the years pass, the demand for Crude Oil increased. As a result, the Crude Oil import started to increase in 2012. 


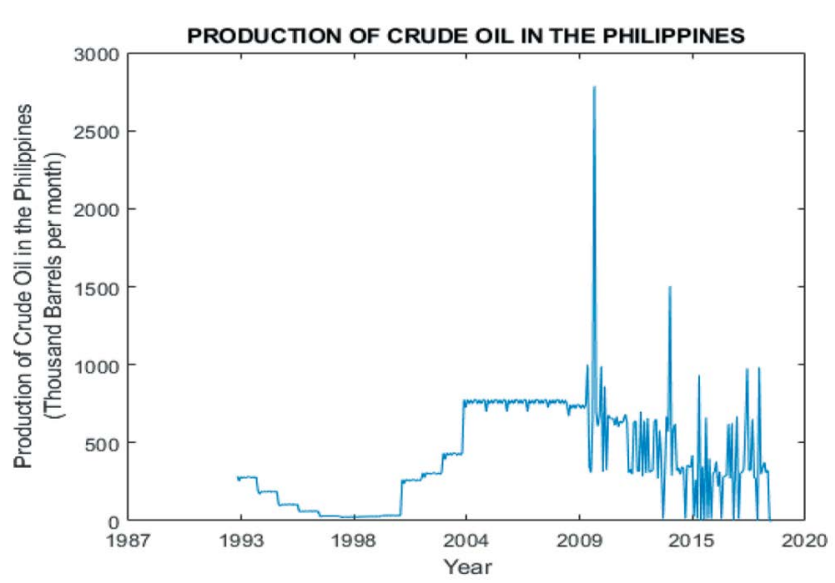

Figure 10. Production of Crude Oil in the Philippines $\left(\mathrm{x}_{6}\right)$ [January 1993 - September 2018].

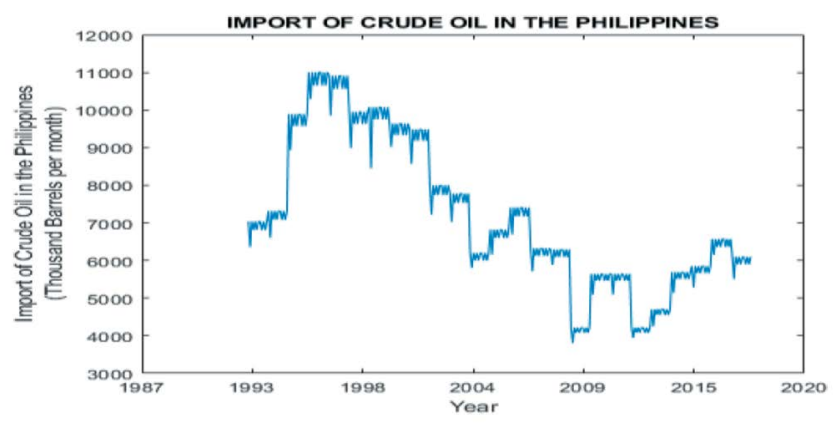

Figure 11. Import of Crude Oil in the Philippines $\left(\mathrm{x}_{7}\right)$ [January 1993 - September 2018].

\subsubsection{Export of Crude Oil}

The Crude Oil export in the Philippines declined until it dropped to zero from 1995 to 2007 as displayed in Figure 12. Then, the export of Crude Oil records became incoherently fluctuating and unstable. Though Philippine exports of Crude Oil varied considerably in recent months, it declined through January 2014 to December 2018 period ending at 10.55 thousand barrels per day in December $2018^{35}$.

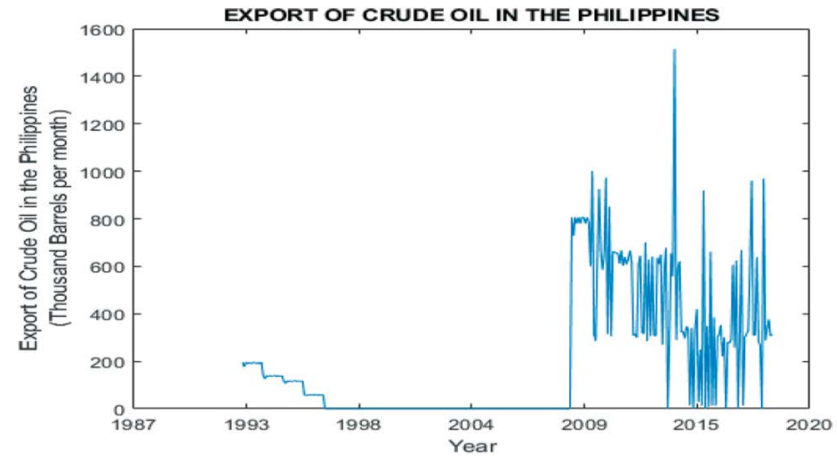

Figure 12. Export of Crude Oil in the Philippines $\left(\mathrm{x}_{8}\right)$ [January 1993 - September 2018].

\section{Significant Relationship of the Dependent and Independent Variables}

\subsection{Crude Oil Price and Exchange Rate}

Exchange rate and Crude Oil price in the Philippines from January 1993 to September 2018 were depicted in Figure 13. It shows a weak positive correlation and the variables are directly related. To conclude, as the exchange rate increases, the Crude Oil price also increases.

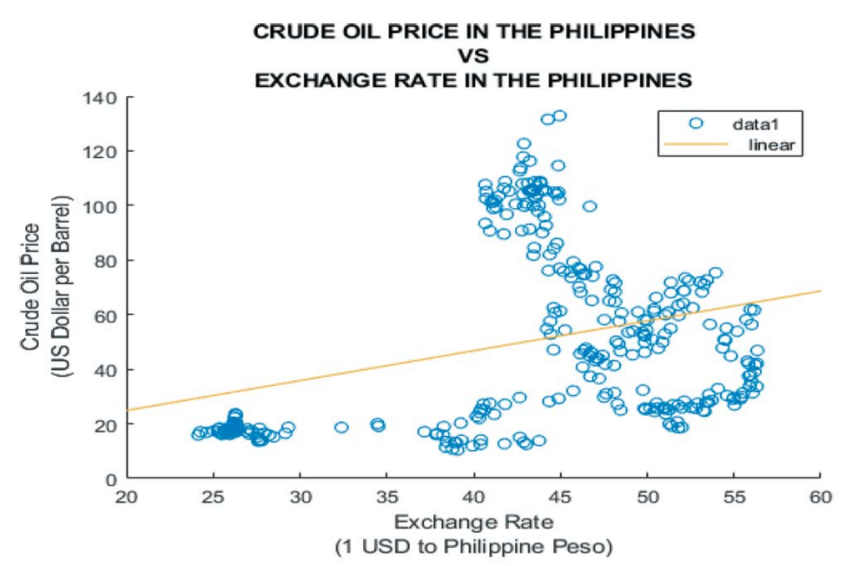

Figure 13. Crude Oil price in the Philippines (y) vs. Exchange rate in the Philippines $\left(\mathrm{x}_{1}\right)$.

\subsection{Crude Oil Price and Inflation Rate}

The graph exhibits the inflation rate and the Crude Oil price in the Philippines from January 1993 to September 2018. Furthermore, Figure 14 indicates a weak negative correlation and an inverse relationship between the variables. To conclude, as the inflation rate increases, the Crude Oil price decreases.

\subsection{Crude Oil Price and Consumer Price Index}

Figure 15 presents the consumer price index and the Crude Oil price of the Philippines from January 1993 to September 2018. The graph designates a moderate positive correlation and a direct relationship between the consumer price index and the Crude Oil price. Hence, as the consumer price index increases, the Crude Oil price also increases. 


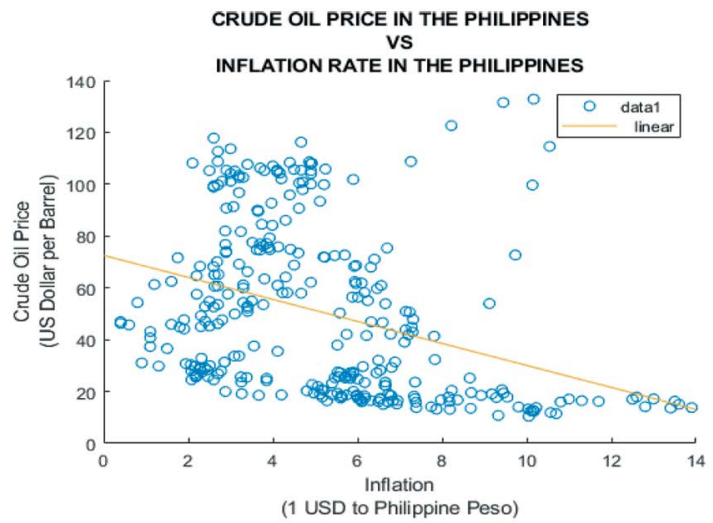

Figure 14. Crude Oil price in the Philippines (y) vs. Inflation rate in the Philippines $\left(\mathrm{x}_{2}\right)$.

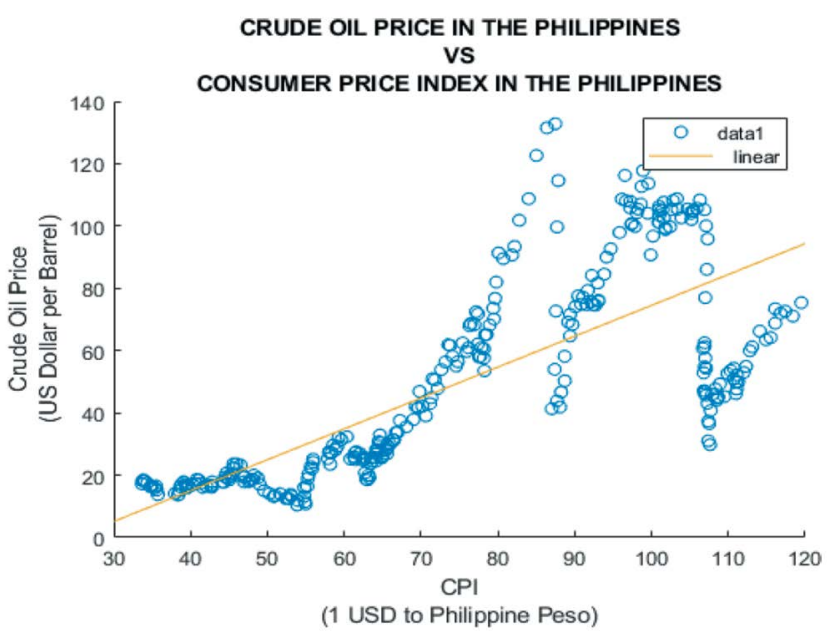

Figure 15. Crude Oil price in the Philippines (y) vs. Consumer price index in the Philippines $\left(\mathrm{x}_{3}\right)$.

\subsection{Crude Oil Price and Domestic Interest Rate}

The interest rate and Crude Oil price in the Philippines from January 1993 to September 2018 are depicted in Figure 16. It expresses a moderate negative correlation and an inverse relationship between the domestic interest rate and Crude Oil price. Hence, as the interest rate increases, the Crude Oil price decreases.

\subsection{Crude Oil Price and Consumption of Crude Oil}

Figure 17 illustrates the consumption of Crude Oil and Crude Oil price in the Philippines from January 1993 to September 2018. The graph portrays a weak negative correlation and an inverse relationship between Crude

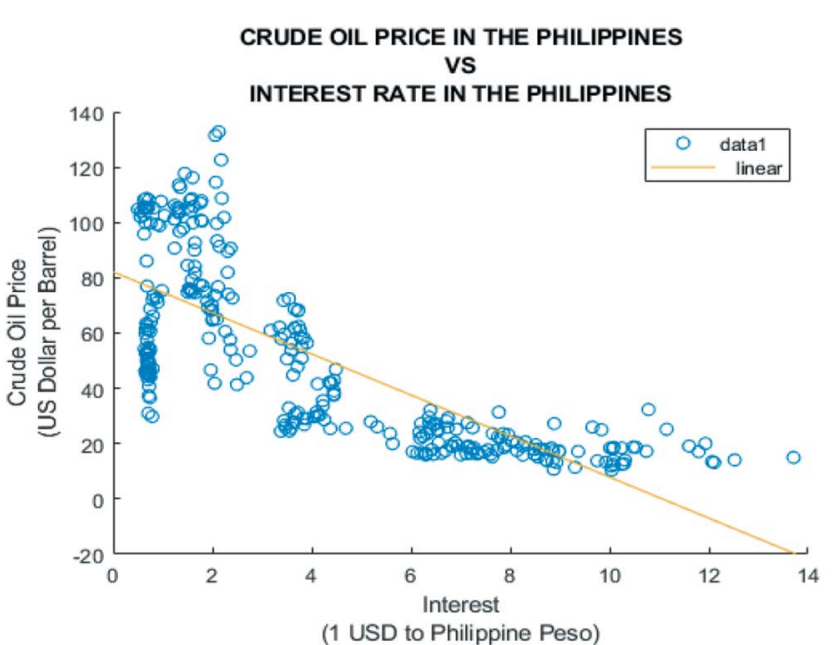

Figure 16. Crude Oil price in the Philippines (y) vs. Domestic interest rate in the Philippines $\left(\mathrm{x}_{4}\right)$.

Oil price and consumption of crude oil. Hence, as the consumption of Crude Oil increases, the Crude Oil price decreases.

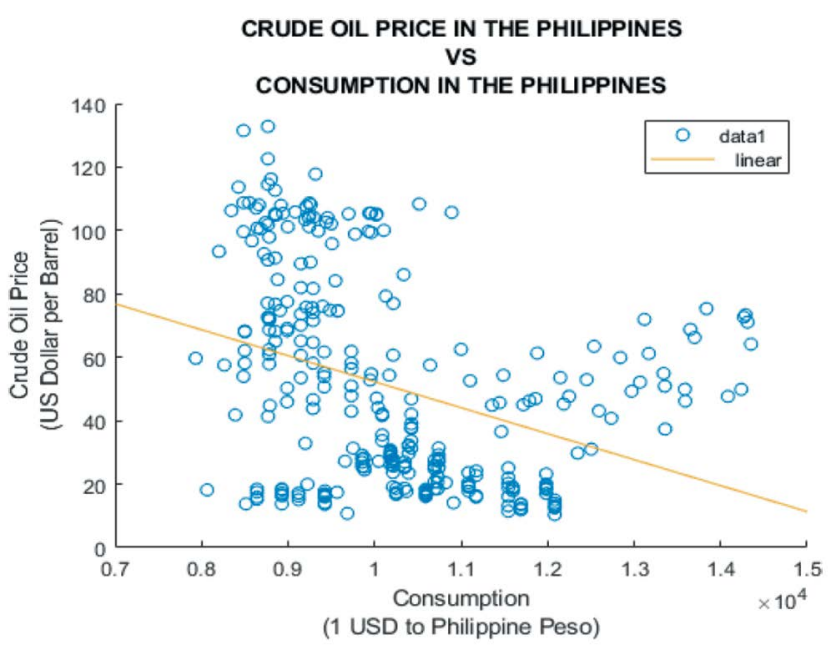

Figure 17. Crude Oil price in the Philippines (y) vs. Consumption of Crude Oil in the Philippines $\left(\mathrm{x}_{5}\right)$.

\subsection{Crude Oil Price and Production of Crude Oil}

The production of Crude Oil and the Crude Oil price in the Philippines from January 1993 to September 2018 were shown in Figure 18. It indicates a moderate positive correlation and a direct relationship between the two variables. Hence, as the production of Crude Oil increases, the Crude Oil price also increases. 


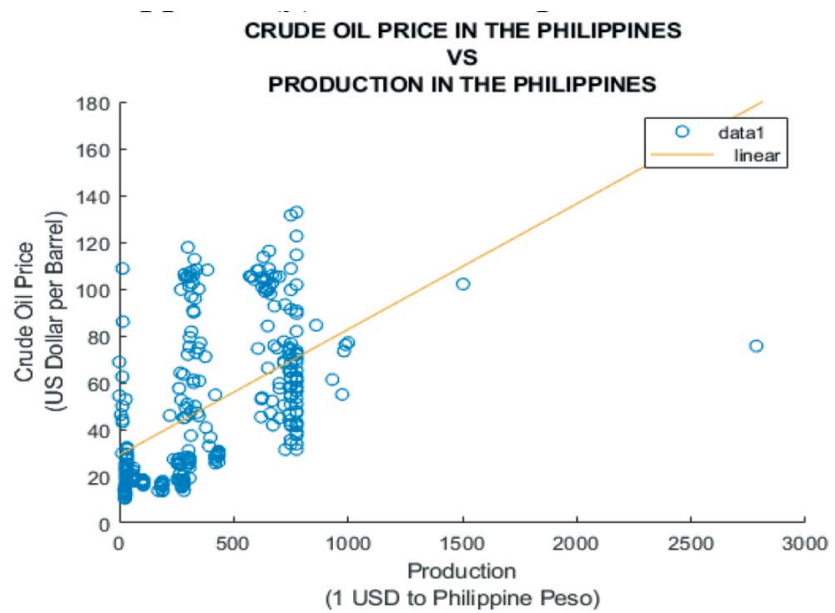

Figure 18. Crude Oil price in the Philippines (y) vs. Production of Crude Oil in the Philippines $\left(\mathrm{x}_{6}\right)$.

\subsection{Crude Oil Price and Import of Crude Oil}

Figure 19 shows the import of Crude Oil and the Crude Oil price in the Philippines from January 1993 to September 2018. Moreover, it depicts a moderate negative correlation and an inverse relationship between the two variables. As the import of Crude Oil increases, the Crude Oil price decreases.

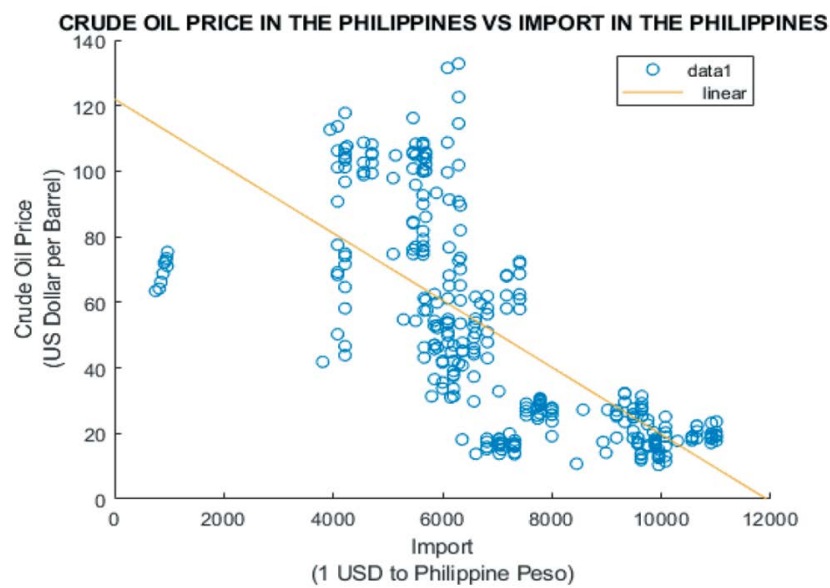

Figure 19. Crude Oil price in the Philippines (y) vs. import of Crude Oil in the Philippines $\left(\mathrm{x}_{7}\right)$

\subsection{Crude Oil Price and Export of Crude Oil}

The export of Crude Oil and the Crude Oil price in the Philippines from January 1993 to September 2018 were displayed in Figure 20. Furthermore, it denotes a moderate positive correlation and a direct relationship between the two variables. Hence, as the export of Crude Oil increases, the Crude Oil price also increases.

The decision made for all independent variables is Reject as shown in Table 1. So, the independent variables that are significantly correlated are exchange rate, inflation rate, consumer price index, interest rate, consumption, production, import, and export of Crude Oil in the Philippines.

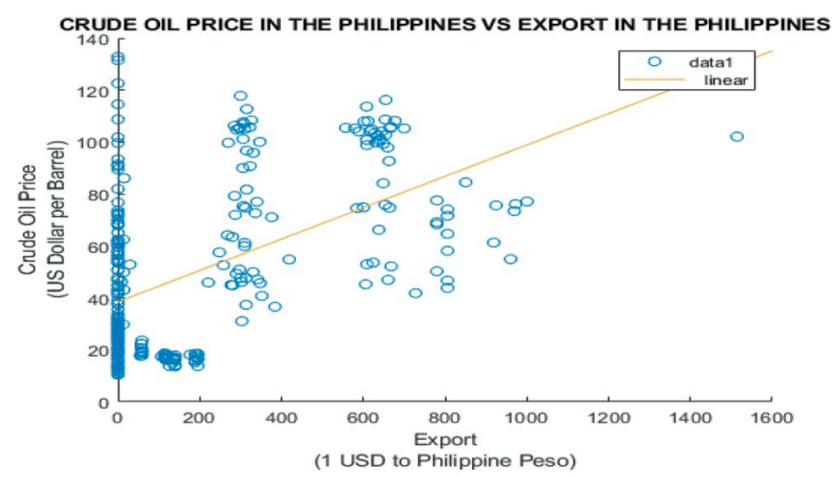

Figure 20. Crude Oil price in the Philippines (y) vs. export of Crude Oil in the Philippines (x8).

\section{Multiple Linear Regression}

The $\mathrm{p}$-values of the exchange rate $\left(\mathrm{x}_{1}\right)$ and the production of Crude Oil $\left(\mathrm{x}_{6}\right)$ are both greater than 0.05 which is the significance level based on Table 2. This means that the insignificant predictors for the Crude Oil price include exchange rate $\left(\mathrm{x}_{1}\right)$ and the production of Crude Oil $\left(\mathrm{x}_{6}\right)$. On the other hand, the significant predictors for the Crude Oil price in the Philippines are Inflation Rate $\left(\mathrm{x}_{2}\right)$, Consumption of Crude Oil $\left(\mathrm{x}_{5}\right)$, Import of Crude Oil $\left(\mathrm{x}_{7}\right)$, and Export of Crude Oil $\left(\mathrm{x}_{8}\right)$. (Figure 19).

\subsection{Multiple Linear Regression Model $\hat{Y}=158.16334-1.44849 x_{2}-0.00570 x_{5}-0.00710 x_{7}$ $+0.01696 x_{8}$}

\subsection{Nonlinear Auto-regressive Exogenous Neural Network}

By using the NARX Neural Network on the significant predictors, the prediction of the Crude Oil Price in the Philippines is completed. Training the network, as shown in Figure 21, using Bayesian regularization will generate the model of the network. The NARX Neural Network Model is shown in Figure 22. Two types of NARX Neural Network Model are explained in the study. These are the 
Table 1. Pearson correlation coefficient for independent variables vs. Crude Oil price

\begin{tabular}{|l|c|c|c|c|c|}
\hline Variable & Pearson $\mathrm{r}$ & Verbal Interpretation & p-value & Decision & Remarks \\
\hline Exchange Rate $\left(\mathrm{x}_{1}\right)$ & 0.3144 & Weak positive & 0.0000 & Reject & Significant \\
\hline Inflation Rate $\left(\mathrm{x}_{2}\right)$ & -0.3560 & Weak negative & 0.0000 & Reject & Significant \\
\hline Consumer Price Index $\left(\mathrm{x}_{3}\right)$ & 0.7561 & Moderate positive & 0.0000 & Reject & Significant \\
\hline Interest Rate $\left(\mathrm{x}_{4}\right)$ & -0.7636 & Moderate negative & 0.0000 & Reject & Significant \\
\hline Consumption of Crude Oil $\left(\mathrm{x}_{5}\right)$ & -0.3527 & Weak negative & 0.0000 & Reject & Significant \\
\hline Production of Crude Oil $\left(\mathrm{x}_{6}\right)$ & 0.5389 & Moderate positive & 0.0000 & Reject & Significant \\
\hline Import of Crude Oil $\left(\mathrm{x}_{7}\right)$ & -0.7037 & Moderate negative & 0.0000 & Reject & Significant \\
\hline Export of Crude Oil $\left(\mathrm{x}_{8}\right)$ & 0.5183 & Moderate positive & 0.0000 & Reject & Significant \\
\hline
\end{tabular}

Table 2. Multiple Linear Regressions estimate coefficient

\begin{tabular}{|c|c|c|c|c|}
\hline Variable & $\begin{array}{c}\text { Beta } \\
\text { Parameter }\end{array}$ & p-value & Decision & Remarks \\
\hline (Intercept) & 158.16334 & 0.00000 & Reject & Significant \\
\hline $\begin{array}{l}\text { Exchange } \\
\text { Rate }\left(\mathrm{x}_{1}\right)\end{array}$ & 0.02712 & 0.89107 & $\begin{array}{l}\text { Failed to } \\
\text { reject }\end{array}$ & $\begin{array}{c}\text { Not } \\
\text { Significant }\end{array}$ \\
\hline $\begin{array}{l}\text { Inflation Rate } \\
\left(\mathrm{x}_{2}\right)\end{array}$ & -1.44849 & 0.00776 & Reject & Significant \\
\hline $\begin{array}{l}\text { Consumption } \\
\text { of Crude Oil } \\
\left(\mathrm{x}_{5}\right)\end{array}$ & -0.00570 & 0.00000 & Reject & Significant \\
\hline $\begin{array}{l}\text { Production } \\
\text { of Crude Oil } \\
\left(\mathrm{x}_{6}\right)\end{array}$ & 0.00827 & 0.15352 & $\begin{array}{c}\text { Failed to } \\
\text { reject }\end{array}$ & $\begin{array}{c}\text { Not } \\
\text { Significant }\end{array}$ \\
\hline $\begin{array}{l}\text { Import of } \\
\text { Crude Oil } \\
\left(\mathrm{x}_{7}\right)\end{array}$ & -0.00710 & 0.00000 & Reject & Significant \\
\hline $\begin{array}{l}\text { Export of } \\
\text { Crude Oil } \\
\left(\mathrm{x}_{8}\right)\end{array}$ & 0.01696 & 0.00747 & Reject & Significant \\
\hline
\end{tabular}

NARX Neural Network Model (Closed Loop) as shown in Figure 23 and the NARX Neural Network Model (One Step Ahead) as shown in Figure 24.

When training and testing the network has been done, the predicted and actual values appeared as the output. Figure 25 illustrates that the actual and predicted values are almost the same.

\subsection{Forecasting Accuracy}

Notice that on Table 3, amongst Multiple Linear Regression and NARX Neural Network, the NARX Neural Network has the least error in MAE, MAPE, MSE,

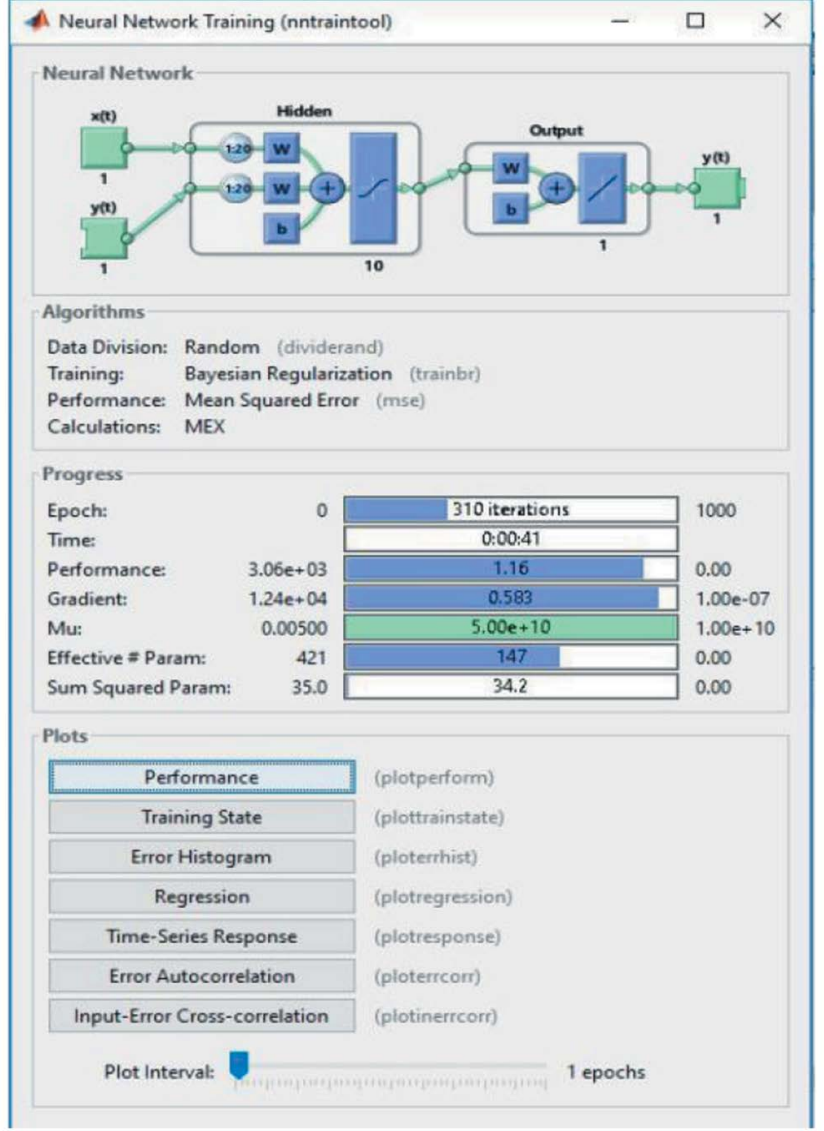

Figure 21. Training the NARX Neural Network.

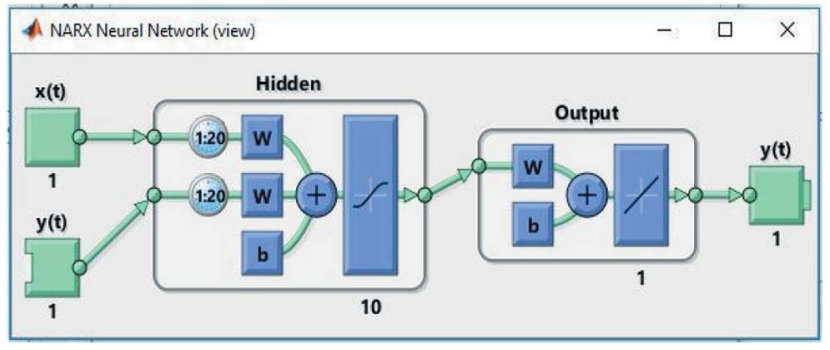

Figure 22. NARX Neural Network model. 


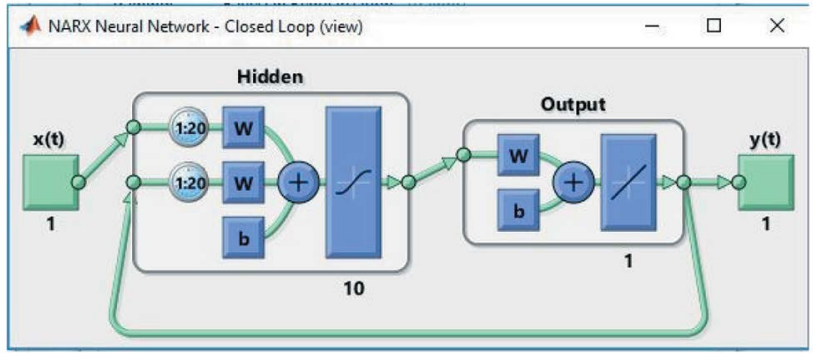

Figure 23. NARX Neural Network model (Closed loop).

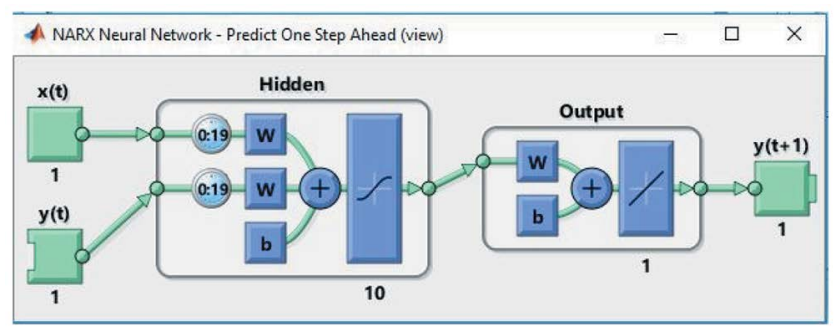

Figure 24. NARX Neural Network model (One step ahead).

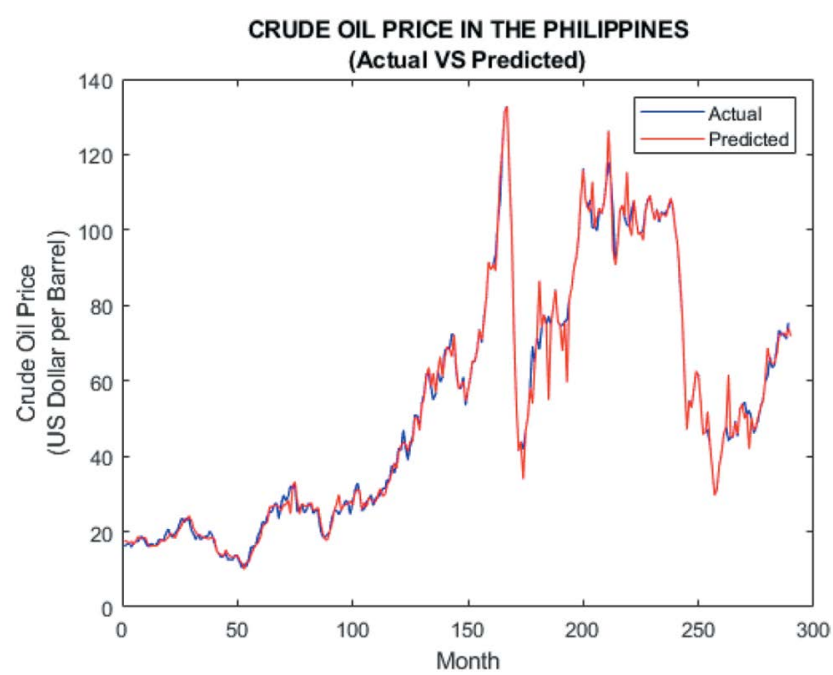

Figure 25. Crude Oil price in the Philippines (actual vs. predicted) [January 1993 - September 2018].

RMSE and NMSE. Thus, the NARX Neural Network is the best-fitted model to forecast the monthly Crude Oil price in the Philippines from October 2018 to December 2023 (Figure 26).

\subsection{Forecasted Values}

The results are presented in Table 4.
Table 3. Forecasting Accuracy of NARX Neural Network and Multiple Linear Regressions

\begin{tabular}{|l|c|c|c|c|c|}
\hline Model & $\begin{array}{c}\text { Mean } \\
\text { Abso } \\
\text { lute } \\
\text { Error }\end{array}$ & $\begin{array}{c}\text { Mean } \\
\text { Absolute } \\
\text { Perce } \\
\text { ntage } \\
\text { Error }\end{array}$ & $\begin{array}{c}\text { Mean } \\
\text { Square } \\
\text { Error }\end{array}$ & $\begin{array}{c}\text { Root } \\
\text { Mean } \\
\text { Square } \\
\text { Error }\end{array}$ & $\begin{array}{c}\text { Norma } \\
\text { lized } \\
\text { Mean } \\
\text { Square } \\
\text { Error }\end{array}$ \\
\hline $\begin{array}{l}\text { Nonlinear } \\
\text { Autoreg } \\
\text { ressive } \\
\text { Neural } \\
\text { Network } \\
\text { with } \\
\begin{array}{l}\text { Exogenous } \\
\text { Inputs }\end{array}\end{array}$ & $\begin{array}{c}1.396 \\
6\end{array}$ & 0.0350 & $\begin{array}{c}10.42 \\
78\end{array}$ & 3.2292 & 10.4278 \\
\hline $\begin{array}{l}\text { Multiple } \\
\text { Linear } \\
\text { Regression }\end{array}$ & $\begin{array}{c}446.2 \\
956\end{array}$ & 21.1257 & 446.2 & 16.2184 & 0.5203 \\
\hline
\end{tabular}

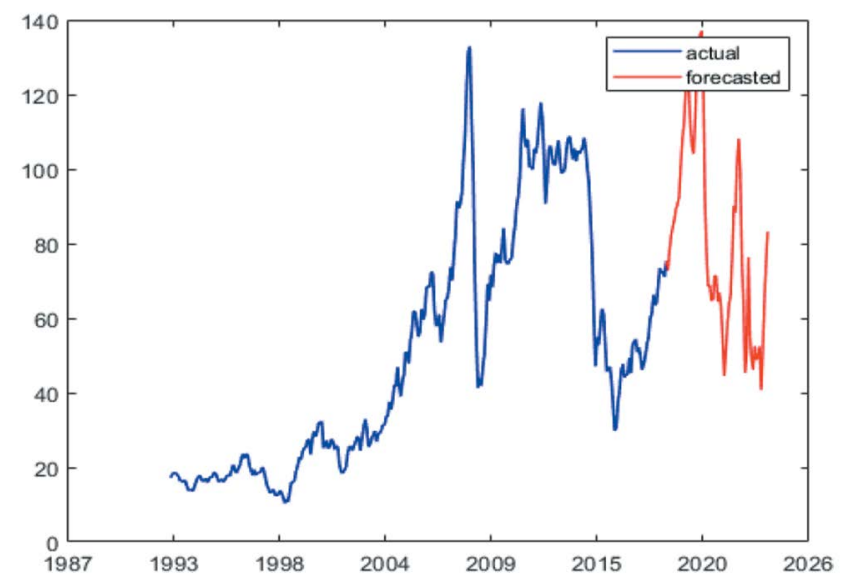

Figure 26. Crude Oil Price in the Philippines (January 1993 - December 2023).

Table 4. Forecasted values (October 2019 - December 2023)

\begin{tabular}{|c|c|c|c|}
\hline Month & $\begin{array}{c}\text { Forecasted } \\
\text { Value }\end{array}$ & Month & $\begin{array}{c}\text { Forecasted } \\
\text { Value }\end{array}$ \\
\hline Oct 2019 & 72.83104 & Feb 2020 & 104.08609 \\
\hline Nov 2019 & 77.98951 & Mar 2020 & 113.44269 \\
\hline Dec 2019 & 81.97331 & Apr 2020 & 128.11649 \\
\hline Jan 2019 & 84.42498 & May 2020 & 132.54935 \\
\hline Feb 2019 & 86.46362 & Jun 2020 & 135.99608 \\
\hline Mar 2019 & 89.19102 & Jul 2020 & 137.03167 \\
\hline Apr 2019 & 90.55060 & Aug 2020 & 122.31086 \\
\hline May 2019 & 92.32133 & Sep 2020 & 91.79235 \\
\hline Jun 2019 & 100.77036 & Oct 2020 & 77.45770 \\
\hline Jul 2019 & 107.76885 & Nov 2020 & 68.52961 \\
\hline
\end{tabular}




\begin{tabular}{|c|c|c|c|}
\hline Aug 2019 & 112.02107 & Dec 2020 & 68.82000 \\
\hline Sep 2019 & 119.90802 & Jan 2021 & 64.86677 \\
\hline Oct 2019 & 124.84380 & Feb 2021 & 64.93806 \\
\hline Nov 2019 & 121.38634 & Mar 2021 & 71.26777 \\
\hline Dec 2019 & 111.25940 & Apr 2021 & 71.23358 \\
\hline Jan 2020 & 106.05671 & May 2021 & 64.49885 \\
\hline Jun 2021 & 66.81687 & Oct 2022 & 45.32770 \\
\hline Jul 2021 & 63.20192 & Nov 2022 & 51.02556 \\
\hline Aug 2021 & 55.23974 & Dec 2022 & 76.32552 \\
\hline Sep 2021 & 44.52223 & Jan 2023 & 54.66482 \\
\hline Oct 2021 & 50.99010 & Feb 2023 & 49.11076 \\
\hline Nov 2021 & 58.52990 & Mar 2023 & 46.18217 \\
\hline Dec 2021 & 63.78078 & Apr 2023 & 52.49371 \\
\hline Jan 2022 & 66.23530 & May 2023 & 48.89611 \\
\hline Feb 2022 & 77.77859 & Jun 2023 & 49.47138 \\
\hline Mar 2022 & 90.08557 & Jul 2023 & 52.43123 \\
\hline Apr 2022 & 88.39688 & Aug 2023 & 40.74764 \\
\hline May 2022 & 101.32493 & Sep 2023 & 51.87792 \\
\hline Jun 2022 & 108.16402 & Oct 2023 & 64.94534 \\
\hline Jul 2022 & 98.95199 & Nov 2023 & 74.95147 \\
\hline Aug 2022 & 74.79764 & Dec 2023 & 83.16272 \\
\hline Sep 2022 & 64.15802 & & \\
\hline
\end{tabular}

Nonlinear Auto-regression Exogenous Neural Network (NARX), NARX Neural Network is the best-fitted model for forecasting the Crude Oil price in the Philippines (y). These significant predictors were used in forecasting, through the use of the NARX neural network. After training and implementation in the results of the neural network, the output showed that the actual and predicted values are very close, that is there is just a very small error or difference between them. Moreover, the NARX Neural Network was able to forecast the future values of Crude Oil price in the Philippines from October 2018 to December 2023.

\section{Recommendation}

For future studies, we recommend using another approach in predicting and forecasting Crude Oil prices in the Philippines (y) such as ARIMA, etc. Furthermore, we recommend using another Artificial Neural Network such as RBFNN.

\section{References}

1. Crude Oil prices: A historical perspective. 2012. https:// www.philstar.com/business/2012/04/25/800023/crude-oilprices-historical-perspective

10. Conclusion and Recommendation

\subsection{Conclusion}

To distinguish which factors should be deliberated in forecasting the Crude Oil Price in the Philippines (y), significant relationship should be present among them. Using the Pearson's $r$, the researchers were able to denote that the independent variables, Exchange rate $\left(\mathrm{x}_{1}\right)$, Inflation rate $\left(\mathrm{x}_{2}\right)$, Consumer price index $\left(\mathrm{x}_{3}\right)$, Domestic interest rate $\left(\mathrm{x}_{4}\right)$, Consumption of Crude Oil $\left(\mathrm{x}_{5}\right)$, Production of Crude Oil $\left(\mathrm{x}_{6}\right)$, Import of Crude Oil $\left(\mathrm{x}_{7}\right)$ and Export of Crude Oil in the Philippines $\left(\mathrm{x}_{8}\right)$ are all significantly related. The independent variables are then retested with the use of Multiple Linear Regression. Interpreting the results, the researchers distinguished that there are four significant predictors for forecasting the Crude Oil Price in the Philippines (y), namely Inflation Rate $\left(\mathrm{x}_{2}\right)$, Consumption of Crude Oil $\left(\mathrm{x}_{5}\right)$, Import of Crude Oil $\left(\mathrm{x}_{7}\right)$ and Export of Crude oil $\left(\mathrm{x}_{8}\right)$. Comparing the forecasting accuracy of multiple linear regression and

2. Philippine national oil company. 2017. http://www.pnoc. com.ph/aboutpnoc.php?sectionid=ac587724-1514-11dfa7de-92d1637a39b1\&menuid=74a17d33ffbf162a259c21fc $4 \mathrm{e} 6 \mathrm{e} 8 \mathrm{fdf}$

3. PNOC Exploration Corporation. 2017. http://www.pnoc. com.ph/subsidiaries.php?sectionid=e4f3bb95-1514-11dfa7de-92d1637a39b1

4. Service contract no. 37 cagayan 2. 2019. http://pnoc-ec. com.ph/service-contract-no-37-cagayan-2/

5. Philippine oil deregulation - A policy research analysis. 2017. https://epusenergy.com/philippine-oil-deregulationa-policy-research-analysis/

6. Malampaya: The future of energy now. 2015. https://www. shell.com.ph/media/media-releases/2015-media-releases/ malampaya-the-future-of-energy.html

7. PNOC Renewables Corporation. 2015. http://www.pnoc. com.ph/subsidiaries.php?sectionid=e4f3bb95-1514-11dfa7de-92d1637a39b1\&menuid=a66575dd-15cf-11df-bb83ela07d93674e

8. Top 10 Crude Oil suppliers to the Philippines. 2019. http:// www.philippinesaroundtheworld.com/top-10-crude-oilsuppliers-to-the-philippines/ 
9. Gachiri CN. An application of multiple regressions in exchange rate arrangement. Department of Natural Statistics, University of the Western Cape, South Africa; 2007. p. 1-59.

10. Izni BM, Radzuan R. A study on prediction of output in oilfield using multiple linear regressions. International Journal of Applied Science and Technology. 2011; 1(4):107-13.

11. Khan Z, Pathak DK, Pandey A, Kumar S. Performance evaluation of nonlinear autoregressive with exogenous input (NARX) in the foreign exchange market. Proceedings of 10th IRF International Conference; Chennai, India. 2014. p. 1-5.

12. Mohamed I. Multiple linear regression model of inflation rate in Sudan. African Journal of Social Sciences. 2015; 5(1):81-91.

13. Hmilad M, Irnawaty R, Samiappanmarappan I. Regression analysis to forecast Malaysia's imports of crude material. International Journal of Management and Applied Science. 2015; 1(4):121-30.

14. Gulumbe SU, Suleiman S. Asare BK, Abubakar M. Forecasting volatility of Nigerian crude price using nonlinear auto-regressive with exogenous (NARX) inputs model. Imperial Journal of Interdisciplinary Research. 2016; 2(5):434-8.

15. Shahbazi N, Memarzadeh M, Gryz J. Forex market prediction using NARX Neural Network with bagging. MATEC Web of Conferences. 2016; 68:19001. https://doi. org/10.1051/matecconf/20166819001

16. Chaudhuri TD, Ghosh I. Artificial Neural Network and time series modelling based approach to forecasting the exchange rate in a multivariate framework. Journal of Insurance and Financial Management. 2016; 1(5):92-123.

17. Wang K, Liu H. Regression analysis of influencing factors on the future price of Crude Oil. Research on Modern Higher Education. 2017; 2:97-101. https://doi.org/10.24104/ rmhe/2017.02.01015

18. Adebayo AM, Suleman I. Comparison between multiple linear regression and principal component regression models in the study of dynamic of inflation on food items in Nigeria. International Journal of Innovative Mathematics, Statistics and Energy Policies. 2017; 5(4):10-8.

19. Multivariate forecasting of Crude Oil spot prices using neural networks. 2018. https://arxiv.org/abs/1811.08963

20. Lucia C, Serban M. New approaches of NARX-based forecasting model. A case study on CHF-RON exchange rate. Informica Economica. 2018; 22(2):5-13. https://doi. org/10.12948/issn14531305/22.2.2018.01
21. Alredany WHD. A regression analysis of determinants affecting Crude Oil price. International Journal of Energy Economics and Policy. 2018; 8(4):110-9.

22. Boussaada Z, Curea O, Remaci A, Camblong H, Bellaaj NM. A Nonlinear Autoregressive Exogenous (NARX) Neural Network model for the prediction of the daily direct solar radiation. Energies. 2018; 11:620. https://doi.org/10.3390/ en 11030620

23. Correlation (Pearson, Kendall, Spearman). 2019. https:// www.statisticssolutions.com/correlation-pearson-kendallspearman/.

24. Design time series NARX feedback neural networks. 2019. https:/www.mathworks.com/help/deeplearning/ug/ design-time-series-narx-feedback-neural-networks.html;js essionid $=6 \mathrm{~d} 89601 \mathrm{~d} 42433 \mathrm{~b} 74 \mathrm{~d} 2 \mathrm{~b} 899400 \mathrm{f} 6 \mathrm{~b}$

25. Pearson's correlation coefficient. 2019. http://learntech. uwe.ac.uk/da/Default.aspx?pageid $=1442$

26. The multiple linear regression equation. 2016. http:// sphweb.bumc.bu.edu/otlt/MPH-Modules/BS/ BS704-EP713_MultivariableMethods/BS704-EP713_ MultivariableMethods2.html

27. MAE and RMSE - which metric if better? 2016. https:// medium.com/human-in-a-machine-world/mae-andrmse-which-metric-is-better-e60ac3bde13d

28. Mean Absolute Percentage Error. 2017. https://www. statisticshowto.datasciencecentral.com/mean-absolutepercentage-error-mape/

29. NMSE. 2017. https://www.mathworks.com/matlabcentral/ fileexchange/62813-nmse

30. Mean square error: Definition and examples. 2019. https:// study.com/academy/lesson/estimation-of-r-squared-variance-of-epsilon-definition-examples.html

31. Economy of the Philippines. 2017. https://en.m.wikipedia. org/wiki/Economy_of_the_Philippines?fbclid=IwAR31N ion3jPzvYkU_hezrtiGva3bn8E4PgBVfL1lTHbxShcvJG2pVbUT9cw

32. Asian financial crisis. 2019. https://www.investopedia.com/ terms/a/asian-financial-crisis.asp

33. Economic history of the Philippines. 2019. http://factsanddetails.com/southeast-asia/Philippines/sub5_6g/ entry-3916.html

34. Philippines total petroleum consumption. 2019. https:// knoema.com/atlas/Philippines/topics/Energy/Oil/ Petroleum-consumption

35. Philippines - Exports of Crude Oil including lease condensate. 2019. https://knoema.com/atlas/Philippines/topics/ Energy/Oil/Exports-of-crude-oil 